\title{
THE PITFALLS OF RIBA OR INTEREST-BASED FINANCING
}

\author{
Abdul Karim Abdullah*
}

\begin{abstract}
Interest-based financing presents a number of pitfalls to individuals, business firms, as well as governments. Each of these pitfalls alone constitutes a compelling reason for abandoning this hazardous mode of financing and replacing it with financing on the basis of risk sharing, such as the mudarabah and mushārakah. The major pitfalls include the inherent inefficiency of lending at interest, the profoundly destabilising effects it has on economic activity, and the crippling indebtedness of nations, firms, as well as individuals that it brings about. The paper investigates these shortcomings, and recommends utilising risk sharing partnerships as a way of avoiding the pitfalls of interestbased financing.
\end{abstract}

\section{Introduction}

Financing is the process of funding personal, corporate, and government spending. It requires identifying and utilising a suitable method of raising funds. Invariably, in any financing arrangement, whether it is a loan or a business partnership, a transfer takes place from those with a surplus to those with a shortage of funds. Parties who are short of funds raise them from parties that have a surplus.

Funds can be obtained by borrowing or in the case of businesses, by means of profit- and loss-sharing contracts. When funds are supplied in the form of loans, the providers of capital are rewarded in the form of interest. When funds are raised by way of profit and loss sharing agreements, the suppliers of capital are rewarded with a share of the profits generated by the businesses they help to finance.

Financing by borrowing at interest presents a number of hazards - one might say pitfalls, to both lenders and borrowers. Some pitfalls arise in practice, others in theory. The pitfalls, especially those facing individual borrowers as well as society at large, are rarely highlighted in the literature on finance, conventional or Islamic. This paper highlights three pitfalls that arise in practice: a less efficient allocation of resources, economic instability, and personal, corporate and government indebtedness. ${ }^{1}$ In addition, it highlights some pitfalls that arise in the theory of finance, in particular from the way certain terms, in particular "efficiency", are used in the discourse of finance. 
The point made in relation to the last pitfall is that to view financial markets, in particular credit markets, as having the capacity to ensure the efficient allocation of resources in the real sector markets is unwarranted. The incentives that ensure an efficient allocation of resources in the real markets (profits) simply do not exist in the financial markets. Trading activity in the financial markets is largely driven by incentives that reward the transfer of wealth rather than its production. ${ }^{2}$ Rewarding unproductive activity, however, inevitably results in a significant waste or inefficient allocation of resources. ${ }^{3}$

The pitfalls of interest-based financing manifest themselves in a variety of ways and at different levels. In some cases, a given pitfall may appear in one form in one place and in another form in another place. Thus, an imbalance in a market in the form of a surplus or a shortage may appear as an instance of instability from one perspective, and at the same time as evidence of inefficiency from another perspective.

We address these pitfalls one by one and, where suitable, demonstrate how they relate to other pitfalls. We conclude by recommending phasing out financing at interest and replacing it with financing on the basis of profit and loss sharing. For profit and loss sharing enables a more efficient allocation of resources, brings greater stability, and also protects parties in need of financing from indebtedness. In general, financing by way of profit and loss sharing promotes sustainable and balanced economic growth over the longer term significantly more effectively than does financing by way of interest-based lending.

\section{Inefficiency}

Efficiency has both a narrow (microeconomic) and a broad (macroeconomic) meaning. In its microeconomic sense, efficiency signifies the ability of a firm to produce a good quality product at a low cost. Lower unit costs bring higher profits, assuming other factors remain constant. In so far as increasing efficiency enables businesses to increase profits, all businesses aim at realising efficiency.

In the macroeconomic sense, efficiency is the ability of the economy to produce the maximum amount of wealth over a given period of time, utilising all of its resources, without giving rise to any persistent shortages or surpluses. ${ }^{4}$ This means that whenever employment remains below full employment (there is a surplus of labour), or prices remain or become unstable (inflation takes place) a degree of inefficiency arises. ${ }^{5}$

Government policies at the macroeconomic level, like corporate policies at the microeconomic level, seek to establish and maintain a regulatory framework that is conducive to the realisation of efficiency. This requires setting up and 
maintaining a structure of incentives that promotes efficiency at both levels. ${ }^{6}$ When the structure of incentives is such that it enables the realisation of efficiency, both the individual firm as well as the economic system can be expected to perform well, resulting in higher profitability, higher output, and a better standard of living.

When the system of incentives is distorted or flawed in some way, however, inefficiencies will occur. At the microeconomic level inefficiency will arise in the form of shortages and surpluses, while at the macroeconomic level it will take the form of inflation, unemployment and sluggish economic growth. Under such conditions, the economy will perform at below optimal levels, resulting in a lower standard of living. Thus, from the point of view of public policy, it is essential to ensure that the incentive structure is such as to reward real contribution to production, rather than different types of rent seeking, in particular rent in the form of interest.

Interest constitutes a poor incentive for ensuring efficiency in the allocation of resources since income "earned" by passive lending rather than by active participation in economic activity essentially rewards people for remaining idle or unproductive. With the legalisation of lending at interest, however, the incentive for remaining idle has effectively been institutionalised. However, the rising costs, personal as well as social, of interest-based financing make it clear that another look at this mode of financing is required to determine whether it indeed serves the interests of society as claimed by its supporters, rather than only those of a few wealthy lenders.

Remarkably, the institutionalisation of interest-based financing is routinely justified by the claim that it helps to allocate resources efficiently, supposedly by "rationing" capital only to businesses that are profitable enough to pay the price (interest) of capital demanded by financial institutions. ${ }^{7}$

While it is true that interest-based financing channels capital only to enterprises sufficiently profitable to pay the required rates of interest, the fact that capital comes at a price - a minimum price - also means that all businesses unable to pay this price will remain without loan financing. In particular, it excludes the SMEs, the small and medium sized businesses. ${ }^{8}$ The small, medium and start-up businesses, due to the intensely competitive environment in which they have to operate, often have razor-thin profit margins.

Since the profit margins tend to be the lowest in the most competitive industries, the requirement to pay interest for capital effectively disqualifies from loan financing precisely those firms that most deserve to receive it, i.e., the most competitive and efficient firms. 


\section{Consequences of Costly Capital}

The fact that capital comes at a cost introduces inefficiency into every market within the economic system, starting with the capital market. As all markets depend on, or are linked to the financial sector in one way or another, the inefficiency that first arises in the capital markets eventually spreads to all other markets.

At the microeconomic level, inefficiency arises in the form of surpluses in the product and resource markets. ${ }^{9}$ At the macroeconomic level, inefficiency takes the form of inflation (rising cost of living and production), unemployment (waste of human resources), and slower economic growth (lower standard of living).

Evidence of inefficiency arises first in the financial markets in the form of a surplus of capital. ${ }^{10}$ What causes the surplus is the fact that capital comes at a price. A minimum price of capital causes a surplus of capital just as a minimum price of labour causes a surplus of workers (unemployment) in the labour market. ${ }^{11}$

Inefficiency caused by the surplus of capital in the financial market then spreads to the product markets in the form of inflation, arising from the need to include the cost of financing in the prices of final goods and services.

Inflation, arising as a result of firms passing their interest expenses on to consumers in the form of higher prices, reduces the demand for goods and services. As a result of reduced aggregate demand, a surplus of unsold goods develops. The need to cut back production levels in response causes some workers to be laid off. This causes inefficiency in the labour market in the form of unemployment (surplus of labour). ${ }^{12}$

Rising unemployment in the labour market in turn worsens the surplus in the product markets. A decline in the disposable income of households, reduced as a result of a rise in unemployment, then causes an additional reduction in aggregate demand, spending and production.

Finally inefficiency in the product and labour markets brings a reduction in overall GDP growth rate. A decline in economic growth takes place as a result of a decline in sales caused by rising prices and a decrease in disposable income, caused by a rise in unemployment. Additional reduction of economic growth takes place as a result of the need to divert funds from spending towards the repayment of debt.

Inefficiency will also surface in the foreign sector. Inflation in the product markets makes exports more expensive and thereby causes a deficit on the current account (an excess of payments for imports over receipts from exports). Rising prices of local goods reduces exports and leads to an increase in demand for comparatively less expensive imports.

A deficit on the current account puts downward pressure on the value of the domestic currency and causes disequilibrium in the foreign exchange markets (a 
surplus of local currency). The downward pressure on the local currency forces the central bank to raise interest rates. Higher interest rates, however, will attract inflows of funds on the capital account (which records cross-border flows of capital for purposes other than trading). This will cause a surplus on the capital account. ${ }^{13}$

Thus in all these ways, what was an initial inefficiency in the capital markets in the form of a surplus of funds caused by the "cost" of financing eventually begins to spread through all other markets and effectively destabilises the entire economic system. ${ }^{14}$

\section{Reward and Performance}

In principle, the inefficiency of interest-based financing arises from the fact that a lender is able to "earn" (interest) income without giving up anything of value in exchange to earn it, in other words without adding value. ${ }^{15}$

No businessman would pay a wage to a worker without expecting a palpable contribution to production. Yet an exception to this appears to take place in the lending of capital. Unlike everyone else, lenders are able to obtain (interest) income from borrowers without making any tangible contribution or effort to production. ${ }^{16}$

The amount of interest paid by borrowers to lenders is normally agreed upon, and sometimes fixed, in advance. This means that the amount of interest paid does not - and indeed cannot - depend on the efficiency or profitability of the enterprises lenders finance. There is effectively no link between the amount of interest paid to lenders and the profitability (efficiency) of the enterprises they finance.

The absence of the link between reward and performance, however, gives lenders little reason to invest capital in any enterprises that are more profitable (efficient) than what it takes to repay debt with interest. As long as an enterprise is able to repay debt and provide acceptable collateral, its relative efficiency is of little concern to the lender. Thus, lenders sometimes finance even projects with uncertain prospects of success. ${ }^{17}$

Examples of a waste of resources (or malinvestment as Hayek called it) attributable to interest-based lending abound. They include the surplus of properties financed by subprime mortgage in the US, as well as the surplus of properties in Dubai, likewise financed by borrowing. Yet despite clear evidence of the inefficiency of interest-based financing, few economists appear to question the suitability of lending at interest for ensuring the efficient allocation of resources. ${ }^{18}$

In contrast to interest-based lending, in financing by way of profit and loss sharing the rewards (profits) to the suppliers of capital (shareholders) are firmly linked, and indeed depend on, the efficiency (profitability) of the enterprises they finance. While shareholders may not participate on a day-to-day basis in 
the affairs of the enterprises they finance, and therefore are not rewarded for any "work" performed for the company, their rewards depend of the performance of the businesses they finance. ${ }^{19}$

In lending, however, not only does the reward of the lender not depend on the lender's productivity (as the lender, like the shareholder does not directly participate in production), it does not even depend on the productivity (profitability) of the enterprise the lender helps to finance. The reason is quite simple: the amount of interest paid to lenders cannot depend on the amount of profit earned since the quantum of interest paid to the lender is determined in advance and profits cannot be known in advance.

Investors in profit and loss sharing contracts face risks of losses, and this gives them a powerful market incentive to exercise due diligence in allocating their resources wisely, to the most efficient and profitable businesses. This holds true both before and after committing funds. Thus, only businesses with strong and credible prospects of success can expect to obtain financing. Businesses with limited prospects of commercial success will find it hard to attract funding, and this ensures a more efficient (less wasteful) allocation of resources. ${ }^{20}$

A necessary condition for the realisation of efficiency is for reward to depend on performance (productivity). This is a central pillar of the free enterprise economy. The link between reward and effort ensures that payments to a factor of production, assuming other factors remain constant, depend on, and indeed are proportionate to its productivity (efficiency). Indeed, this is why workers paid on the basis of piecework tend to be more productive (and also earn higher incomes) than workers that are paid on a salaried basis, where no direct link between productivity and reward exists.

The inefficiency of interest-based financing can be overcome by utilising profit and loss sharing contracts, that reward only genuinely productive activity. This will also eliminate all other forms of efficiency that arise in various markets, beginning with the capital market, as a result of the fact that capital comes at a cost.

\section{Instability}

The inefficiency of interest-based financing gives rise to various types of surpluses and shortages. Insofar as these represent market imbalances, they signify instability.

Stability is the capacity of a person, object or system to resist change. When we describe a person, object or a system as stable, we mean that the condition, position, or composition of the person, object or system is unlikely to change or change easily. Stable does not mean static, as change can take place in a stable way. Stability can be broadly contrasted with chaos. 
Stability, or the absence of a propensity to change, takes many forms, including physical, psychological, or systemic. We speak of a stable aircraft, a stable person, or a stable system. This could be an economic system, a political system or an ecosystem. Different types of stability, such as economic and political stability, generally reinforce each other. In principle, a condition of stability is to be preferred to instability, although stability is not necessarily desirable for its own sake. A prisoner may be leading a stable existence; this does not mean, however, that a life in prison is desirable.

The Qur'an mentions "stability" (qarar), in the context of contrasting a good word with an evil word. ${ }^{21}$ Good and evil words are compared to trees. Each type of tree brings forth a different kind of fruit. An old adage says, "a tree is known by its fruit." A good word is like a tree that is firmly rooted or stable; the evil word, by contrast, "has no stability" 22 and is likely to collapse at any time. ${ }^{23}$ Following divine guidance is like having one's feet "planted firmly," 24 and "grasping a firm handle-hold." 25

In general, instability is hazardous, as it brings many risks. Thus we speak of an unstable marriage or an unstable person. Political and economic instability are likewise to be avoided. ${ }^{26}$ Islam enhances stability by means of both commands and prohibitions. It promotes stability by prohibiting destabilising practices such as gambling, consuming intoxicants, and "earning" riba. While gambling destabilises people financially, consuming intoxicating substances destabilises people physically as well as intellectually. Borrowing at interest destabilises individuals, businesses, and entire nations financially.

Islam also enhances stability by mandating practices that have a stabilising effect. These include performing prayers, paying zakah and fasting. Achieving and maintaining stability helps to realise the objectives (maqasid) of the Shariah: protection of life (arising from a reduction of crime), protection of the family (arising from preventing marriage breakdown), and the protection of property (arising from avoiding financial crises, indebtedness and bankruptcies).

At the macroeconomic (national and global levels), instability manifests itself in the form of business cycles. These are periods of accelerating growth followed by slow or negative growth and stagnation. Business cycles that become particularly severe are known as crises. In principle, instability in the interestbased system of financing arises from an increase in spending, made possible by borrowing, that is then followed by a reduction in spending, brought on by the need to repay debt with interest.

Historically, a number of business cycles stand out as having caused a great deal of hardship. These include the crisis of 1929-1933 (the Great Depression), the 1973 oil crisis, the commodities crisis of 1987, the currency crisis of 1997, the dotcom bust of 2001, and the global financial crisis that started in 2007 and 
shows no signs of abating. These crises have taken, and continue to take, a heavy toll on people, businesses and entire nations.

Friedman, Hayek and other leading economists have observed that monetary policies of central banks, despite all good intentions, can cause a significant degree of instability. What is less frequently noted is that in the longer term, and in contrast to financing on the basis of profit and loss sharing, financing at interest causes cyclical instability regardless of whether central banks keep interest rates constant, or allow them to fluctuate with market conditions.

Instability caused by financing spending by means of borrowing takes place as follows: an expenditure of borrowed funds initially boosts aggregate demand (AD) in all categories, consumer, producer or government; an increase in spending causes a decline in inventories of finished products; an increase in sales triggers an increase in production, investment, and employment; additional resources, including human resources, are then engaged in the production process and economic growth accelerates.

Because of the increase in demand financed by the borrowed funds, however, prices in product and resources markets begin to rise. Thus, the first effect of financing spending by borrowing is inflation. Prices in product and resources markets rise because borrowing enables all sectors, e.g., households, firms, as well as governments, to claim a share of GDP that is larger than their current income and savings allow them to claim. Were consumers, producers and governments compelled to finance their spending out of savings or income, this inflation would not arise in the first place.

The increase in demand made possible by the ability to spend through borrowing well beyond the limits of one's savings and income, causes "asset bubbles," particularly in the property and the share markets. The rising prices of assets (which often serve as collateral for loans) encourage more lending and spending. Any increases in spending financed by credit will be magnified by the multiplier. This period of economic expansion, financed by spending borrowed funds, represents the "boom" stage in the business cycle.

After the initial surge in demand (caused by the expenditure of borrowed funds), rising prices as well as the need to repay debt begin to restrain spending. As the economy overheats, central banks raise interest rates, thereby restraining spending by making both consumer and business borrowing more expensive. In time a sufficiently large spike in interest rates will reverses the expansion process. ${ }^{27}$ This will initiate the contraction stage of the business cycle.

The multiplier effect will again magnify the change - now a reductionin spending. Reduced spending will cause a rise in inventories and trigger a reduction in production of goods and services. A decline in production reduces growth, investment, employment, as well as profits. 
Some borrowers become unable to continue servicing their loans. Falling asset prices reduce the market value of the collateral pledged for loans. Bankruptcies, both personal and business, are likely to rise. This represents the "bust" phase of the business cycle. At this stage some investment projects are likely to be abandoned. ${ }^{28}$

Thus, credit financing exacerbates business cycles by enabling increases in spending to take place, financed by borrowing, that are subsequently followed by decreases in spending, necessitated by the need to repay debt.

To make matters worse, since the amount that borrowers are obliged to repay is always higher, on account of interest, than what they borrowed initially, the overall reduction in spending during the repayment stage (leakages) will invariably be greater than any initial increase in spending (injections) during the growth phase.

Thus, whatever boost was given to economic activity by an initial expenditure of borrowed funds is more than offset by subsequent reductions in spending, necessitated by the need to repay debt with interest. This means that the net effect on aggregate demand (and therefore on GDP) over the entire cycle of borrowing, spending, and repayment, can only be negative.

Put differently, spending money borrowed at interest stimulates economic growth in the short run only by reducing it by a still greater amount in the long run. In this way, to finance spending through borrowing is only to thwart, rather than foster economic growth over the long term. Moreover, since spending and repayment of debt take place on a personal as well as the national level, the effects of changes in overall spending are felt far and wide.

Aggravating the downturn in economic activity is the absence of any guarantee that funds flowing back into the financial institutions in the form of repayments of loans with interest will be recycled into the real sector. Even if the funds are recycled, there is no guarantee that they will re-enter the real sector in a timely fashion or in the necessary amounts. A delay or shortfall in the recycling of such funds is likely to make the contraction worse.

Extending more debt, whether to private businesses or governments, merely postpones solving the underlying problem, and may in fact magnify it. The shortterm solution is to write off all accumulated interest charges, ${ }^{29}$ and even the principal amounts owed. ${ }^{30}$

The long-term solution to the problem of instability caused by interest-based financing is to adopt profit and loss sharing as the preferred mode of financing. This would compel households as well as businesses to live within their means, without spending in excess of their means. Utilising profit and loss sharing would also relieve businesses and government of the need to pay interest and reduce the burden represented by the national debt on both current and future generations. 


\section{Indebtedness}

Financing by way of borrowing obliges the borrower, whether a person, a firm or a government, to go into debt. Because it imposes a future obligation on the debtor, going into in debt puts pressure on him to make good his promise to repay. This pressure increases with the amount owed and the interest rate charged.

Going into debt obliges borrowers to become beholden to creditors. Indebtedness places borrowers at the "service" of the creditors, for at least as long as it takes to repay (service) the debt. Thus, borrowing from the outset establishes a relationship of inequality between debtor and creditor. This is at odds with the teaching of Islam, which emphasises that at the level of dignity, human beings are all created equal. "We have bestowed dignity on the children of Adam," says a well-known verse in the Qur'an. ${ }^{31}$

Debt presents risks not only to creditors but also to debtors. While the risks of lending to creditors are often highlighted, the same cannot be said about the risks to debtors. The risk to the lender, except in cases of collateralised lending, is that a borrower may fail to repay the debt or a part of it to the lender. ${ }^{32}$ The risk to the borrower is that he or she may suffer damage to his or her reputation as a result of inability to repay debt and possibly be blacklisted as a result.

Moreover, being in debt can turn into being trapped in debt, as a result of an increase in debt, from interest and compound interest charges added on top of the original loan. A debt trap is a condition of being in debt and unable to come out of it. Going into debt is easier than coming out of it, as the repayment of money borrowed at interest always exceeds the initial amount borrowed. ${ }^{33}$

Going into debt enables people to by-pass the natural limits on spending (income and savings) and to spend, as well as live, beyond their means. ${ }^{34}$ Problems arise when debtors are faced with the need to repay debt and find that they are unable to do so for some reason, such as a lower than expected income. ${ }^{35}$

This holds true even when the loan is interest-free, but it is worse when the loan is made at interest. On what grounds would a person willingly expose himself to the risks presented by going into debt? The answer most likely has to do with need. People go into debt because they feel they have little other choice.

The amount of debt currently outstanding is unprecedented. At the same time, a small number of people (in particular shareholders of financial institutions) have amassed vast fortunes. A number of industrialised nations currently suffer from a debt "overhang." The US owes \$ 15 trillion of 100 per cent of GDP. ${ }^{36}$ Japan's debt stands at 170 per cent of GDP (or 94 per cent if reserves of foreign exchange are taken into account). ${ }^{37}$ The economic problems due to the need to repay debt with interest are worst in heavily indebted countries such as Greece, Spain and Ireland, all reeling under their debt burdens. 
In the US, household debt amounts to $\$ 3$ trillion, on which $\$ 300$ billion of interest is paid yearly. Developing nations are not spared large debts. Mexico had massive debt problems in 1984-1985. A number of Latin American countries such as Argentina defaulted outright on their foreign debts. Given the number of personal and business bankruptcies in many countries, including the bankruptcies (sovereign default) and near bankruptcies of entire nations, the inability to repay debt with interest and "serial default" have become a fact of life. In many parts of the world, debt-restructurings have become common. Sovereign defaults (defaults by governments) are far more common than is generally realised.

The danger over the longer term is that as growing proportions of wages, profits, and tax revenues are diverted to repay debt, progressively less money remains available for spending on consumption, investment and the provision of essential public services. ${ }^{38}$ In this way, the reduction in spending, caused by the need to repay debt with interest, reduces aggregate demand and therefore economic growth. This can result in a vicious spiral: first, taxes need to go up in order to repay debt. ${ }^{39}$ Higher taxes, however, reduce consumption and investment. A reduction in consumption and investment spending slows down economic growth. A declining, stagnant or negative growth in turn means a decline in government tax revenue. A reduction in tax revenue worsens the (budget) deficit and makes it still harder to repay debt. Taxes may have to go up again, and the same cycle repeats itself.

Rogoff and Krugman refer to the current economic slowdown, the most pronounced since the Great Depression, as the Second Great Contraction. ${ }^{40}$ In the two years after the 2008 subprime mortgage crisis, global GDP declined by 6 per cent. In many industrial countries, including the US and the UK, economic stagnation continues. Unemployment levels are high, especially among younger people. The need to divert tax revenue to repay debt is necessitating "austerity measures" and "belt-tightening."

The solution to the problem of large and growing debts, public or private, lies in phasing out financing at interest and replacing it with financing on the basis of profit and loss sharing. This will leave all money earned in the form of wages, rents and profits within the real sector (the circular flow), and make it unnecessary to borrow it at a cost (interest) from the financial institutions in order to finance consumption, investment or government spending.

\section{Analytical pitfalls}

While a number of pitfalls arise in the practice of interest-based financing, other pitfalls may be found in the discourse of finance. Indeed, the latter pitfalls may well explain the former pitfalls. 
The discourse of a given discipline provides the parameters within which analysis takes place. Depending on its comprehensiveness as well as ability to integrate new insights, academic discourse presents opportunities but may also impose limitations on what can be conceptualised. Thomas Kuhn had already noted some of the challenges in attempting to rehabilitate an existing paradigm (way of looking at things) or introduce a new one and the resistance one can expect from parties with an interest in maintaining the status quo. ${ }^{41}$

A lack of clarity in the understanding of key economic terms, or of the way key institutions work and relate to each other, may result in a flawed understanding of how the economic system functions. Analyses resting on a problematic articulation of the meaning of key terms (such as riba), institutions (such as markets), or incentives (such as profits) may cause a profound misunderstanding of the dynamics of economic activity. This can result in the adoption of policies that may turn out to be detrimental and even counterproductive over the longer term. Such policies do not serve the public interest (maslahah) but may on the contrary undermine it in unforeseen ways.

The pitfalls in the discourse of finance commonly take the form of unwarranted assumptions about the meaning of key expressions. ${ }^{42}$ One key term that has been affected in this way is "efficiency."

In the real sector, the term efficient is applied to a worker, a business, or a system. It refers to the ability of a worker, a business or a system to generate new wealth in a way that minimises waste and maximises output (production). It is seldom applied to a market, except insofar as markets help in assisting to allocate resources efficiently.

In finance, however, the term efficiency is used differently. Unlike in economics, in finance the term efficient is applied almost exclusively to markets. The allocation of resources hardly ever gets a mention. Thus, in finance the term efficiency is not - at least not explicitly - applied to the way resources are allocated. The term efficiency is used in a narrow sense, where it is restricted to the ability of markets to determine prices accurately.

The view that financial markers are efficient in the sense that they determine prices accurately is known as the "efficient market hypothesis" (EMH). This hypothesis says that the market price of an asset always reflects its true value. ${ }^{43}$ The efficient market hypothesis is part of the classical theory of economics, which sees markets as efficient not only in the way they determine prices but also in the way they allocate resources.

The fact that over the long term prices are determined accurately and resources allocated efficiently in the real sector does not yet mean, however, that the same can be expected to take place in the credit markets. One of the major fallacies in contemporary finance is to think that what markets can achieve in the real sector, they can also achieve in the credit sector. 
Credit markets do not operate in the same way as real sector markets. Thus, just because real sector markets in the absence of market and regulatory failure are able to allocate resources efficiently, it does not follow that credit markets can do the same. In other words, the classical "efficient market hypothesis" still holds true, but only for the real sector markets, and even that only over the longer term, and not for credit markets. ${ }^{44}$

Recent experience in fact has disproved not only the claim that financial markets determine prices of securities accurately in the financial sector, ${ }^{45}$ but also that they ensure an efficient allocation of resources in the real sector. Evidence of inefficiency of the credit markets appears in the form of the massive quantity of resources that have been channelled (and wasted) in the construction of houses financed by subprime mortgages. This has also been seen in the overinvestment in the property sector that took place in Dubai, using similar debt-like instruments of financing.

The claim that credit markets are efficient, and the implication that they also help to allocate resources efficiently in the real sector, has facilitated the flow of large amounts of resources into wasteful uses. In order to prevent a similar waste in future, it has to be recognised that financial markets, in particular credit markets, do not operate in the same way as other markets, in particular real sector markets. The activities in the two types of markets are driven by radically different incentives, interest on the one hand and profits on the other. One incentive (profit) is conducive for ensuring that resources will be allocated efficiently. The other (interest income) is not.

When functioning in the absence of market and regulatory failure, real sector markets, the product and labour markets in particular, are efficient (over the longer term) both in the sense of determining prices accurately and in the sense of allocating resources efficiently. The same, however, cannot be said about the markets for credit (debt). These have proven themselves, in retrospect, to be inefficient in both ways.

The fundamental inefficiency of credit markets, as argued elsewhere in this paper, stems from the fact that capital comes at a cost. As long as capital comes at a cost, inefficiencies will persist. Thus, to eliminate the full range of inefficiencies caused by interest-based financing, a different mode of financing, in particular profit and loss sharing, needs to take its place. When this happens, the inefficiencies caused in the real sector by interest-based financing will be eliminated.

One may add that the ability of prices to determine prices accurately is only one of the conditions, even if an important one, of achieving macro-economic efficiency. For the latter to take place, other conditions need to be fulfilled. These include the need to ensure that resources flow into the real economy and that investment takes place in the real sector. 
These conditions also include the need to implement a regulatory framework and a system of incentives that reward real investment (production of wealth) rather than unproductive speculation (transfer of wealth) such as takes place in the trading of securities in the financial markets. ${ }^{46}$ The contemporary discourse of finance appears to be largely silent on these other conditions.

Above all there is the need to share investment risk. Risk constitutes a powerful incentive for exercising due diligence, a sine qua non of an efficient allocation of capital. It is the possibility (risk) of suffering losses, more than any other factor, that acts as a powerful incentive to investors to allocate resources carefully. Where investors feel there is little or no risk, they may commit resources on a scale greater than is justified by a more accurate assessment or risk.

Rather than seeking to devise ways of sharing risk, however, conventional finance, and to a worrying extent Islamic finance, has been seeking to reduce risk for lenders, if not completely eliminate it. The reduction of risk to lenders is accomplished simply by transferring it to borrowers.

The belief that risk could be eliminated by transferring it to borrowers or insurers turned out to be unfounded. The risk was transferred, but not eliminated. Moreover, third parties (such as AIG) to whom the risk was transferred turned out to be unable to bear it. In the end, the risk was transferred to the taxpayers.

The risk was overlooked in part because a great many of the investments were touted as collateralised, in particular the "collateralised debt obligations" (CDOs). ${ }^{47}$ Thus, in a bizarre turn of events, the very securities - products of "financial innovation" - that were supposed to reduce the risks for investors not only did not protect investors from risks but in fact made investors more vulnerable to risk by giving them a false sense of security.

Investors who hedged their investment by purchasing credit default swaps to protect themselves against defaults of the CDOs fared no better, in so far as a number of companies that sold this "protection", such as AIG, themselves did not hedge their own positions and went bankrupt precisely at a time when they were expected to save their counterparties from bankruptcy. Another factor that was overlooked was that while hedging devices might work in isolated cases of defaults, they would not work in the case of a default on a system wide basis.

The lesson to be drawn from this is that risk transfer neither fosters an efficient allocation of resources nor provides protection against risk. By contrast, risk sharing does both. It reduces risks to investors and fosters the efficient allocation of resources - at the same time.

The belief that financial markets, and in particular credit markets, are efficient is one of the major fallacies in the contemporary discourse of finance. The fallacy is due to the failure to differentiate between real sector markets and credit markets and the belief that credit markets operate in the same way as real sector markets do. 
The failure to differentiate between the two types of markets is in turn due to the failure to understand how each type of market operates and how the incentives that drive it operate. In order to set finance on the right footing, a better understanding of markets and how they operate is therefore required.

By adopting a restricted meaning of efficiency as the ability of markers to determine prices, finance has effectively excluded macro-economic (social) consideration from its discourse. Thus, finance uses what may be thought of as a "privatised" notion of efficiency. Yet this "private" notion of efficiency appears to have not only entered, but even come to dominate, the public discourse on efficiency. A notion of efficiency that has been stripped of its social significance may serve private interest well. However, it is not clear how such a meaning can serve the public interest (maslahah) ${ }^{48}$

Thus, there is a need to re-establish the link between the meaning of efficiency as it is understood in finance and how it is understood in the real sector, a link that has been severed in the new discourse and practice of finance. More specifically, the scope of the dominant meaning of efficiency needs to be broadened, to include social goals, such as an achieving stable prices, full employment and sustainable economic growth. ${ }^{49}$

For this to happen, the understanding of efficiency needs to be rooted in the real sector because it is in the real sector that goods and services that meet social needs are produced. It is only on the basis of a broader understanding of efficiency that the macro-economic objectives of economic activity (social well being) can be comprehensively articulated and successfully implemented.

\section{Conclusions and Recommendations}

The basic inefficiency of interest-based lending, the various forms of instability it causes, and the large debts it has given rise to, constitute good reasons for phasing out this mode of financing and replacing it with a mode of financing that is more conducive to economic growth: profit and loss sharing.

Were interest-based financing to be replaced by financing on the basis of profit and loss sharing, the surplus of idle funds commonly found in financial systems that use interest-based financing could be overcome. Specifically, this surplus of funds could be used to finance investment in enterprises currently unable to earn sufficient profits to pay the rates of interest demanded. This would increase investment, reduce unemployment and stimulate economic growth, all at the same time.

In a system of financing on the basis of profit and loss sharing, the funds that previously flowed to financial institutions in the form of interest payments would now flow to the businesses in the form of profits and to workers on the form of 
wages. This means that businesses would have more funds to invest from internal sources. They would no longer have to access funds at a cost and they would no longer have to pass interest expenses on to consumers in the form of higher prices. This would reduce inflation. Extra funds held by business in the form of retained earnings, combined with the higher disposable income of households, would boost aggregate demand and economic activity.

- Awareness needs to be created that interest-based financing, contrary to popular perception, is in fact inefficient and adversely impacts every sector by causing a range of inefficiencies in the economy.

- Awareness also needs to be created about the destabilising effects of interest-based financing, in particular, the link between this mode of financing and cyclical instability. This is a compelling reason for abandoning interest-based financing in favour of profit and loss sharing.

- The dangers of going into debt, personal as well as social, need to be widely publicised. Alternative methods of financing should be explored.

- The discourse of finance needs to be revisited to ensure that the terminology used reflects the economy of the real sector and that key drivers (incentives) of economic activity are properly understood.

- Interest-based financing needs to be phased out and replaced with financing on the basis of profit and loss sharing.

\section{Notes}

* Abdul Karim Abdullah (Leslie Terebessy), Assistant Fellow at IAIS, earned his MA in political philosophy from the University of Toronto, Canada (1999) and a MEd (1986) from the University of Toronto's Ontario Institute for Studies in Education (OISE). A former lecturer, editor, writer and coordinator of the English program at University Sains Islam Malaysia (USIM), his current projects involve research into the current financial crisis, critical thinking in Muslim societies, and Islamic Finance. He has edited Islamic Studies at World Institutions of Higher Learning (Kuala Lumpur: USIM 2004).

1. Other pitfalls include inflation, unemployment, a reduced economic growth over the long term and an inequitable distribution of wealth. These have been addressed at some length in the writer's "The Causes of the Debt Crisis: Interest-based Financing," Islam and Civilisational Renewal 3, no. 4 (July 2012), 679-702.

2. These incentives take the forms of commissions and fees on trades of existing stocks and bonds (debt) or issues of new securities.

3. "The top employees of the five largest investment banks divided a bonus pool of over $\$ 36$ billion in 2007.” Kenneth S. Rogoff and Carmen M. Reinhart, This Time is Different (Princeton and Oxford: Princeton University Press, 2009), 210.

4. James D. Thexton, Economics (Canada: Oxford University Press, 1992), 43.

5. The two types of efficiency are related. Reducing the cost of inputs (a gain in efficiency at the microeconomic level) makes it possible to increase overall output (a gain in efficiency at the macroeconomic level).

6. Muhammad Nejatullah Siddiqi, Banking Without Interest (Leicester UK: Islamic Foundation, 1983), 163.

7. Commission of the European Communities, "Economic Benefits from Financial Integration," Green Paper on Financial Services Policy (2005-2010), Annex 1 Section 1, available online at 
http://eur-lex.europa.eu/LexUriServ/site/en/com/2005/com2005_0177en01.pdf (accessed on 13 October 2012).

8. It has been widely documented that the SMEs also provide the largest number of jobs. Leaving them without funding can only make unemployment worse.

9. While Henry VIII did not formally legalise interest in England until 1545, the practice of charging interest on loans was already widespread, despite being technically illegal. "For about one hundred years, from the early 1500s until the early 1600s, consumer prices in England increased relentlessly. Throughout this period, the prices of food, fuel and clothing advanced five-fold." Jeffrey B. Little and Lucien Rhodes, Understanding Wall Street (PA: Liberty Hall Press, 1991, $3^{\text {rd }}$ ed.), 164.

10. As a consequence, the level of savings (S) will be higher than the level of investment (I). Iraj Toutounchian, Islamic Money and Banking: Integrating Money in Capital Theory, available online at http://www.toutounchian.com/books.htm (accessed on 22 October 2012), 3.

11. Umer M. Chapra, Islam and Economic Development (Islamabad, Pakistan: International Institute of Islamic Thought and Islamic Research Institute, 1993), 7-8.

12. The fact that financial institutions pay interest to depositors, however small, acts as a disincentive to parties with surplus capital to invest their funds for profit. Saving rates which exceed the profits rates of marginally profitable enterprises will thus draw capital away from investment in the real economy into the financial sector.

13. This is indeed what has been taking place for some time now in the US, which has been experiencing large deficits on its current account and large surpluses on its capital account. The US has been importing cheaper goods from nations such as China (thus worsening the deficit on the current account) and at the same time borrowing from them (thus worsening the surplus on the capital account). At the same time, the sales of local goods have been languishing (causing more unemployment in the US) due to their relatively high prices. The amount of US debt held by China has been estimated to exceed US \$ 1 trillion.

14. "Instability originating in the financial sector spreads to the real sector affecting balance of payments, employment, production and living standards." Mohammad Nejatullah Siddiqi, "Islamic Banking and Finance in Theory and Practice: A Survey of State of the Art," Islamic Economic Studies 13, no. 2 (February 2006), available online at http://79.132.221.61/files/

15. takmili/islamic_econ./islamic_banking/vol_13_2..m_n_siddiqi.._isl_banking_and_finance...pdf (accessed on 29 October 2012), 6.

16. We cannot say that the lender gives up the money he lends in exchange, because this money is returned to him when the loan is repaid. At best, the lender gives up the money "for a time." In this case, interest could be viewed as "rent" for the use of the money. But this leaves the problem of paying rent for something that is in itself useless unresolved.

17. The fact that lenders can earn income without giving up any counter value resembles receiving charitable donations. The difference is that donations are made to persons on account of their poverty, while interest payments are made to lenders on account of their wealth, as only wealthy persons are in a position to lend.

18. According to Christopher Bliss, as reported by Robert Skidelsky, "bankers provide credit to investment projects they have only very limited information about." Robert Skidelsky and Christian Westerlind Wigstrom (eds.), The Economic Crisis and the State of Economics (New York: Palgrave Macmillan, 2010), 4.

19. Some economists, including Muslims, appear to subscribe to the view that "there is no such thing as finance without interest." Mahmoud A. El-Gamal, Islamic Finance: Law, Economics, and Practice (Cambridge UK: Cambridge University Press, 2006), 26.

20. Shareholders exert an influence over the management (boards of directors) during the annual general meetings of shareholders (AGMs), where they have the power to elect or dismiss directors from the boards of directors (who in turn appoint the chief executives of the company), and thereby exercise a degree of control over company policy. Lenders as a rule have no comparable control over the companies they finance, unless they also become shareholders, as is the case with some financial institutions in Germany who also buy shares in the companies they finance by way of loans.

21. Siddiqi, "Islamic Banking and Finance in Theory and Practice," 6.

22. Qur'an, 14:24-26.

23. Qur'an, 14: 26.

24. Cf. Qur'an, 9:109. 
25. Qur'an, 47:7.

26. Qur'an, 2:256.

27. Naomi Klein, The Shock Doctrine (UK: Penguin Books, 2007), 424.

28. "The typical story of past recessions is that a booming economy displays increasing indications of inflation. Central banks raise interest rates, bubbles burst, and economies go into recession." Christopher Bliss, "Globalization and the Current Crisis," in: Skidelsky and Wigstrom (eds.), The Economic Crisis and the State of Economics, 67.

29. "In raising the rate of interest to liquidate inflation banks curtail the credit needed to complete the investment projects so investment collapses, and the economy contracts." Skidelsky in The Economic Crisis and the State of Economics, 8.

30. Qur'an, 2:278.

31. Qur'an, 2:280.

32. Qur'an, 17:70.

33. In the US Federal Reserve Chairman Paul Volcker allowed interest rates to increase dramatically in the 1980s. They peaked in 1981 at 21 per cent. This led to a wave of bankruptcies, and "in 1983 the number of people who defaulted on their mortgages tripled." Klein, Shock Doctrine, 159.

34. Inability to repay debt or default is sometimes presented as "debt intolerance". See Kenneth S. Rogoff and Carmen M. Reinhart, This Time is Different (Princeton and Oxford: Princeton University Press, 2009), 21-33.

35. "Credit creation by the banking system produces overinvestment in relation to voluntary saving." Skidelsky in The Economic Crisis and the State of Economics, 8.

36. "What is certainly clear is that again and again, countries, banks, individuals, and firms take on excessive debt in good times without enough awareness of the risks that will follow when the inevitable recession hits." Rogoff and Reinhart, This Time is Different, xxxiii.

37. Approximately half of this debt is owed to foreign lenders, mainly China, Japan, and other countries. Ellen Hodgson Brown, Web of Debt (Baton Rouge LA: Third Millennium Press, 2008), 368.

38. In the US public infrastructure is showing visible signs of deterioration, as there are not enough tax dollars to pay for repairs. A major reason for the shortage of funds is the massive diversion of tax revenue towards the payment of interest on government loans.

39. According to one study authorised by the US Treasury in 2001, in order for the US government to continue servicing its national debt as it has been doing in the past, personal income taxes would have to increase up to 65 per cent by 2013 just to pay the interest charges on the US national debt. Brown, Web of Debt, 368.

40. The first contraction is the Great Depression. Rogoff and Reinhart, This Time is Different, xxix.

41. Thomas Kuhn, The Structure of Scientific Revolutions (Chicago IL: University of Chicago Press, 1996, $3^{\text {rd }}$ ed.).

42. Gail T. Fairhurst, The Power of Framing: Creating the Language of Leadership (San Francisco CA: John Wiley \& Sons, 2011), xiv.

43. John Kay, "Knowledge in Economics," in The Economic Crisis and the State of Economics, 91-92.

44. As noted earlier, we consider the share market to be a real sector market, as share certificates unlike debt instruments - represent the ownership of real assets.

45. Even the claim that markets are efficient in the limited sense of determining prices accurately has not remained unchallenged. Apart from the dramatic declines in the prices of the collateralised debt obligations (CDOs), essentially bundles of mortgages and other loans, another example of an inaccurate market valuation of assets is provided by the collapse of asset prices in Japan, in 1987. As a deluge of selling of securities took place on 19 October 1987 in Japan, "investors woke up to the massive overvaluation of assets." Ann Pettifor, The Coming First World Debt Crisis (New York: Palgrave Macmillan, 2006), 152.

46. These other conditions include specifying what is and what is not permitted in commercial activity. Rules should have as their objective the provision of incentives to reward productive activity and disincentives to discourage wasteful activity.

47. Collateral is an asset that is perceived to eliminate risk for the lender.

48. Mohammad Hashim Kamali, Islamic Commercial Law (Kuala Lumpur: Ilmiah Publishers, 2002), xx-xxi.

49. In America, currently the top 1 per cent of population owns 40 per cent of the nation's wealth. Joseph E. Stiglitz, The Price of Inequality: How Today's Divided Society Endangers Our Future (New York and London: W. W. Norton \& Company, 2012), xi. 